\title{
Plant regeneration in Chlorophytum borivilianum Sant. et Fernand. from embryogenic callus and cell suspension culture and assessment of genetic fidelity of plants derived through somatic embryogenesis
}

\author{
Mohd. Zahid Rizvi • Arun Kumar Kukreja • \\ Narendra Singh Bisht
}

Published online: 29 April 2012

(C) Prof. H.S. Srivastava Foundation for Science and Society 2012

\begin{abstract}
Efficient in vitro propagation of medicinally important endangered plant $C$. borivilianum has been achieved through somatic embryogenesis. Solid embryogenic medium [Murashige and Skoog medium containing $1.79 \mathrm{mM}$ $\mathrm{NH}_{4} \mathrm{NO}_{3}, 10.72 \mathrm{mM} \mathrm{KNO} 3,1.13 \mu \mathrm{M}$ 2,4-dichlorophenoxyacetic acid, $7.38 \mu \mathrm{M}$ 2-isopentenyladenine and $0.76 \mathrm{mM}$ proline] supplemented with polyethylene glycol and sucrose ( $3 \%$ each), exhibited 1.88 -fold increase in embryo maturation compared to embryogenic medium containing $3 \%$ sucrose. Liquid embryogenic medium supported better somatic embryo production and maturation. Highest total (79) and mature (cotyledonary stage) somatic embryos (38) as well as highest germination (57.5\%) was observed at inoculum density of $0.4 \mathrm{~g} / 40 \mathrm{ml}$ of liquid medium. $5.86 \mathrm{pH}$ level exhibited optimal growth, maturation and germination of somatic embryos. Random amplified polymorphic DNA (RAPD) analysis of C. borivilianum plants regenerated through somatic embryogenesis revealed that they were genetically similar to the mother plant. The protocol established in the present study can be used for rapid mass
\end{abstract}

M. Z. Rizvi · A. K. Kukreja $(\varangle)$

Plant Tissue Culture Division,

Central Institute of Medicinal and Aromatic Plants (CIMAP),

Lucknow, P.O. CIMAP-226015, Uttar Pradesh, India

e-mail: akkukreja53@gmail.com

N. S. Bisht

Department of Botany,

Hemwati Nandan Bahuguna Garhwal University (Pauri Campus),

Garhwal-246174, India

Present Address:

M. Z. Rizvi

Department of Botany, Shia Post Graduate College,

Sitapur Road,

Lucknow-226020, India multiplication of $C$. borivilianum in bioreactor employing liquid medium.

Keywords Chlorophytum borivilianum - Genetic fidelity · Maturation - Polyethylene glycol · Somatic embryos

\section{Introduction}

Tuberous roots of monocotyledonous plant safed musli (Chlorophytum borivilianum Sant. et Fernand.) possess immunomodulatory, adaptogenic, aphrodisiac and diuretic properties due to the prescence of steroidal saponins (Kirtikar and Basu 1975; Ramawat et al. 1988; Tandon and Shukla 1995). Saponins are used in the industrial production of sex hormones, corticosteroids and steroid derivatives. The roots are used in the Indian system of medicine for the treatment of general debility, weakness and impotency. They are also used as cardiac and brain tonic; as a curative agent in various diseases like piles, diabetes and as anti-pyretic, diuretic and hemostatic. C. borivilianum has been used in many herbal and Unani formulations in India along with other plants such as Asparagus adscendens, A. racemosum, Curculigo orchioides and Withania somnifera (Kirtikar and Basu 1975; Ramawat et al. 1988). Because of its medicinal properties and diversified uses, there is demand for safed musli especially $C$. borivilianum in India. Many countries in Gulf, Europe and USA have been major importers of the dry roots of safed musli for preparation of various herbal products in pharmaceutical, phytopharmaceutical and nutraceutical industries. While the global demand for dry safed musli roots has been estimated in the order of 35,000 tonnes per annum, the supply stands 
at 5,000 tonnes per year (www.farmwealthbiotech.com, 2010). The plant regenerates in nature sexually by seeds or more frequently by vegetative propagation through shoot buds from perennating root tubers in the soil. It has low seed set, poor seed germination and long dormancy period leading to scarcity of tuberous roots of the plant in nature (Bordia et al. 1995). The slow growth rate in conventional vegetative propagation is not sufficient for meeting demand of this plant (Bordia et al. 1995). Excessive collections from natural habitats and destructive harvesting methods coupled with poor seed germination and low vegetative multiplication ratio have made the species endangered (Gupta and Chadha 1995). The plant has been enlisted as an endangered plant species in Red Data Book of India (Nayar and Sastry 1988) and National Medicinal Plant Board (NMPB), India has categorized it as one of the prioritized plant species to be promoted for conservation and large-scale cultivation and export of this herb is being actively encouraged by Govt. of India through NMPB. The commercial cultivation has been limited due to scarcity of elite and characterized planting material and non-availability of improved agrotechnological practices. Therefore to fill the gap between demand and supply of its tuberous roots to meet industry's requirement and to provide cost-effective genetically uniform planting material for conventional propagation methods at a rapid rate in a short span of time, alternate propagation strategies such as tissue culture are urgently needed which will lead towards conservation and mass production of the plant.

Somatic embryogenesis has become more frequently used technique for large-scale in vitro propagation of plants because it is less labour intensive and thus commercially more viable. The embryogenic suspension culture has great potential for large-scale clonal propagation at rapid rate. Earlier attempts have been made for in vitro propagation of Chlorophytum borivilianum (family Liliaceae) through somatic embryogenesis by Purohit et al. (1994) and Rizvi et al. (2010) but precocious germination of somatic embryos, low germination rate and profuse rooting were observed. Genetic uniformity and stability of the tissue culture raised progeny is an important parameter of a micro-propagation protocol. Although micropropagated plants maintain the genetic fidelity still the possibility of generating somaclonal variations exists (Bindiya and Kanwar 2003). A number of molecular markers can be used to assess the genetic fidelity of in vitro derived plants. However random amplified polymorphic DNA (RAPD) is efficient and cheapest among these markers (Jayanthi and Mandal 2001). In the present investigation, culture conditions were established for improved maturation and germination of somatic embryos and plantlet development in C. borivilianum from embryogenic suspension culture. The genetic fidelity of plants regenerated through somatic embryogenesis was also reported using RAPD markers.

\section{Materials and methods}

Maintenance of mother plants

Mother plants were obtained from natural habitat (Rajsamand District in the State of Rajasthan). Amongst these mother plants, a high yielding line of $C$. borivilianum selected on the basis of root yield in a CIMAP project, was maintained in Botanical Garden of the Institute. This selected high yielding line was used as the initiation plant material. Seeds obtained from this line of $C$. borivilianum were used for callus induction.

Culture initiation and maintenance

Seedlings were obtained from surface sterilized seeds $(0.1 \%, w / v$ aqueous mercuric chloride solution for 5 $6 \mathrm{~min}$ ) germinated in vitro on Murashige and Skoog (MS) medium (1962) supplemented with $57.74 \mu \mathrm{M}$ gibberellic acid $\left(\mathrm{GA}_{3}\right)$. Hypocotyls from seedlings were implanted on optimal callus induction medium i.e. MS medium supplemented with $1.16 \mu \mathrm{M}$ kinetin $(\mathrm{Kn})$ and $1.13 \mu \mathrm{M}$ 2,4-dichlorophenoxyacetic acid (2,4-D), earlier standardized amongst different levels of Kn $(0.47-2.32 \mu \mathrm{M})$ and 2,4-D $(0.45-4.52 \mu \mathrm{M})$ tested in C. borivilianum (Rizvi et al. 2010).

Induction and maintenance of embryogenic callus

Callus obtained on callus induction medium showed optimal embryogenic response on modified MS medium containing $1.79 \mathrm{mM} \mathrm{NH} \mathrm{NO}_{3}, 10.72 \mathrm{mM} \mathrm{KNO} \mathrm{KN}_{3}, 1.13 \mu \mathrm{M}$ 2,4-D, $7.38 \mu \mathrm{M}$ 2-isopentenyladenine (2-iP) and $0.76 \mathrm{mM}$ proline, hereinafter designated as embryogenic medium. This medium was standardized in earlier experiments by testing effects of $\mathrm{NH}_{4} \mathrm{NO}_{3}$ (1.79-10.70 mM yielding $50-300 \mathrm{mg}$ nitrogen), $\mathrm{KNO}_{3}(3.56-21.45 \mathrm{mM}$ yielding $50-300 \mathrm{mg}$ nitrogen), 2,4-D $(0.45-4.52 \mu \mathrm{M}), 2-\mathrm{iP}(0.98-7.38 \mu \mathrm{M})$ and proline $(0.38-2.29 \mathrm{mM})$ on somatic embryogenesis in $C$. borivilianum (Rizvi et al. 2010).

Somatic embryo maturation and germination

In the present study, culture conditions were standardized for efficient maturation and germination of somatic embryos. Experiments were conducted to observe the effect of different carbon sources, osmotica and abscisic acid (ABA) in solid embryogenic medium on somatic embryo maturation and germination. Subsequently effect of different physical states (solid or liquid) of standardized medium on somatic embryogenesis was observed. Experiments were also conducted for observing effect of casein acid hydrolysate $(\mathrm{CH})$, different inoculum density and $\mathrm{pH}$ levels in liquid medium on growth, development and germination of somatic embryos. 


\section{Carbon sources and osmotic agents}

Different carbon sources viz. sucrose, glucose, fructose, lactose, galactose, cellobiose, rhamnose, xylose, arabinose, maltose, mannose, soluble starch (each at $3 \%, w / v$ ) were supplemented to agar-solidified embryogenic medium. Embryogenic medium without any carbon source served as control. Plasmolyzing osmotic agents, D-mannitol or D-sorbitol and non-plasmolyzing osmoticum, polyethylene glycol (PEG, molecular weight 4,000), each at $1-11 \%(w / v)$ were supplemented to embryogenic medium with $3 \%$ sucrose. Embryogenic medium containing $3 \%$ sucrose served as control.

\section{Abscisic acid}

ABA was supplemented in the range of $0.1-7.0 \mu \mathrm{M}$ to embryogenic medium containing $3 \%$ sucrose to observe its effect on somatic embryo maturation. ABA was filter sterilized and added to culture media after it was cooled to about $40{ }^{\circ} \mathrm{C}$ and stored in dark. Control was embryogenic medium with $3 \%$ sucrose.

\section{Physical state of culture medium}

Hypocotyl derived embryogenic callus was inoculated in $40 \mathrm{ml}$ agar-solidified $(0.8 \%, w / v)$ or liquid (without agar) embryogenic medium containing sucrose and PEG $(3 \%$ each). The solid embryogenic medium supplemented with sucrose and PEG (3\% each) served as control.

\section{Casein acid hydrolysate}

Embryogenic cell aggregates were inoculated in liquid embryogenic medium having PEG and sucrose (3\% each) and supplemented with $(1-4 \%, w / v)$ of casein acid hydrolysate $(\mathrm{CH})$. The liquid embryogenic medium supplemented with sucrose and PEG (3\% each) served as control.

\section{Inoculum density and $\mathrm{pH}$ levels}

To analyze the effect of different inoculum densities, $0.1-$ $1.0 \mathrm{~g}$ embryogenic callus was inoculated in $40 \mathrm{ml}$ liquid embryogenic medium containing sucrose and PEG (3\% each). Liquid embryogenic medium having $0.15 \mathrm{~g}$ inoculum density was treated as control. Optimal level $(0.4 \mathrm{~g})$ of embryogenic cell mass was inoculated in liquid embryogenic medium supplemented with sucrose and PEG (3\% each) and having different $\mathrm{pH}$ levels (3.86-7.86 \pm 0.1$)$. The liquid embryogenic medium having $5.86 \mathrm{pH}$ level served as control. The liquid cultures were kept on a rotary shaker (New Brunswick Scientific, USA) at $100 \mathrm{rpm}$ agitation.

\section{Germination of somatic embryos}

Mature (cotyledonary stage) somatic embryos developed on culture media having different treatments were transferred to optimal embryo germination medium i.e. MS medium supplemented with $15.54 \mu \mathrm{M}$ 6-benzylaminopurine (BAP). In our earlier experiments, amongst a wide range of BAP (6.66-28.86 $\mu \mathrm{M})$ tested for their efficacy on somatic embryo germination in $C$. borivilianum, BAP at $15.54 \mu \mathrm{M}$ exhibited optimal germination (Rizvi et al. 2010).

The medium was solidified with $0.8 \%(w / v)$ agar (HiMedia, India). In liquid medium agar was excluded. The $\mathrm{pH}$ of the medium was adjusted to $5.8 \neq 0.1$ (except in case of different $\mathrm{pH}$ levels experiment) using $0.1 \mathrm{~N} \mathrm{HCl}$ or $0.1 \mathrm{~N}$ $\mathrm{NaOH}$ prior to autoclaving at $121^{\circ} \mathrm{C}$ temperature and $15 \mathrm{lb}$ pressure for $20 \mathrm{~min}$. $0.15 \mathrm{~g}$ of callus (except where mentioned otherwise) was inoculated per conical flask $(100 \mathrm{ml}$ capacity, Borosil) containing $40 \mathrm{ml}$ of liquid or solid medium. Each treatment had fifteen replicates and all experiments were repeated thrice. Cultures were maintained in a culture room having $16 \mathrm{~h}$ light $/ 8 \mathrm{~h}$ dark photoperiod, $45 \mu \mathrm{mol} \mathrm{m}^{-2} \mathrm{~s}^{-1}$ light intensity provided by cool white fluorescent tubes (Philips, India), $25 \pm 2{ }^{\circ} \mathrm{C}$ temperature and 50-60\% relative humidity. Observations on callus fresh wt., number of total somatic embryos, number of mature (cotyledonary stage) somatic embryos and number of somatic embryos germinated/20 mature embryos were recorded after 4 weeks.

\section{Hardening and transplantation}

Plantlets obtained from in vitro germinated somatic embryos after 6 weeks of culture of mature somatic embryos on embryo germination medium were hardened in same culture at room conditions as described above for 2 weeks in $1 / 4$ strength MS nutrient solution. These plants were transferred to earthen pots containing sand:soil:farmyard manure in 1:1:1 $(v / v)$ ratio and covered with transparent polythene bags with small holes. The polythene bags were removed after 2 weeks and the surviving plants were maintained in the glass house.

\section{Histological analysis}

Subcultured embryogenic tissues of $C$. borivilianum during 4-6 weeks of culture duration having somatic embryos at different developmental stages were fixed in FAA (formaldehyde:glacial acetic acid:50 \% ethyl alcohol in ratio of 5:5:90, v/v) solution. The tissues were dehydrated through a graded ethanol series (50, 70, 90 and $100 \%)$, embedded in paraffin wax (congealing point $58-60{ }^{\circ} \mathrm{C}$, Qualigens, India) and serially sectioned (8-10 $\mu \mathrm{M}$ thickness). Sections were stained with safranin and light green, mounted in Canada 
Balsom (Thomas Baker, India) and photographed under a photomicroscope (Nikon FX-35 A, Japan).

Genetic fidelity of plants regenerated through somatic embryogenesis: RAPD fingerprinting

Genomic DNA was isolated from fresh and young leaf tissue of 17 C. borivilianum plants after 12 weeks of their transplantation in pots along with mother plant following the modified cetyl trimethyl ammonium bromide (CTAB) method (Khanuja et al. 1999). These 17 plants were randomly selected from progeny of 56 plants regenerated in vitro trough somatic embrogenesis and established in glass house. Quality of the DNA was checked on $0.8 \%(\mathrm{~m} / \mathrm{v})$ agarose gel by loading an aliquot of samples as well as spectrophotometrically (Nanodrop ND-1000, U.S.A.) by measuring the absorbance at $260 \mathrm{~nm}$. Isolated DNA was amplified through polymerase chain reaction (PCR) using twenty different MAP primers (MAP 01 to MAP 20; Bangalore Genei, India). The PCR amplification reactions were carried out using the thermal cycler [DNA Engine PTC-2000 (M.J. Research, USA)] following the protocol of Khanuja et al. (2000). PCR amplification was carried out in $25 \mu$ l volume using 20 decamer primers. The reaction mixture consisted of $25 \mathrm{ng}$ of DNA, 0.6 units of Taq DNA Polymerase, $10 \mathrm{mM}$ of each dNTPs (ATP, GTP, CTP, TTP), $2.5 \mu \mathrm{l}$ of 10X polymerase buffer (100 mM Tris-HCl; pH 8.3, $500 \mathrm{mM} \mathrm{KCland}$ $15 \mathrm{mM} \mathrm{MgCl} 2$ ) and 5 pmol of decanucleotide primer. The amplification products were separated electrophoretically on $1.2 \%$ agarose gel containing $0.5 \mathrm{~g} / \mathrm{ml}$ ethidium bromide using $50 \mathrm{~mA}$ current for $3 \mathrm{~h}$. The bands were visualized and photographed using Gel Documentation System (Pharmacia Biotech, USA). Bands were scored as present or absent for each sample including both micropropagated as well as mother plant. RAPD bands within samples were scored as missing if they were poorly resolved on the gel or if the tempelate DNA did not amplify well. The RAPD experiments were repeated twice to confirm the consistency of results.

\section{Results and discussion}

Maturation and germination of somatic embryos

Carbon sources, osmotic agents and abscisic acid

Amongst all carbon sources added to solid embryogenic medium, highest number of total (44) and mature (17) somatic embryos were observed on sucrose (3\%), (Table 1; Fig. 1a) followed by ghucose and maltose. Somatic embryogenesis was not observed in control medium (solid embryogenic medium without any carbon source) and medium supplemented with arabinose, galactose, lactose and soluble starch. The mature (cotyledonary) somatic embryos produced on embryogenic medium containing $3 \%$ sucrose showed higher germination (30\%) on transfer to embryo germination medium (MS medium supplemented with 15.54 $\mu \mathrm{M}$ BAP), (Table 1; Fig. 1e). The type of carbon source can play vital role in somatic embryogenesis. In Pandx vietnamensis, sucrose at $3 \%$ level was most effective for somatic embryogenesis as compared to glucose and fructose (Nhut et al. 2011). In the studies of Gerdakaneh et al. (2009) also, sucrose was the best carbon source for induction and development of somatic embryos. Hong et al. (2008) reported that in somatic embryogenesis of Oncidium, maltose was less effective as compared to sucrose
Table 1 Effect of different carbon sources on somatic embryogenesis in Chlorophytum borivilianum

\section{(a)}

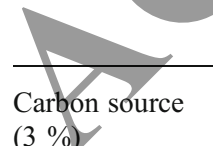

No. of total somatic embryos
No. of mature (cotyledonary) embryos
No. of embryos germinated/20 mature embryos

\begin{tabular}{|c|c|c|c|c|c|}
\hline & Control $^{\mathrm{a}}$ & - & - & - & - \\
\hline & Sucrose & $44.00 \pm 2.21^{\mathrm{b}}$ & $17.00 \pm 1.24$ & $6.00 \pm 1.00$ & 30.00 \\
\hline & Glucose & $41.00 \pm 2.10$ & $14.00 \pm 1.05$ & $4.00 \pm 0.67$ & 20.00 \\
\hline & Fructose & $27.00 \pm 1.24$ & $3.00 \pm 0.66$ & $1.00 \pm 0.47$ & 5.00 \\
\hline & Lactose & - & - & - & - \\
\hline & Galactose & - & - & - & - \\
\hline MS medium & Cellobiose & $22.00 \pm 1.22$ & $2.00 \pm 0.66$ & $1.00 \pm 0.47$ & 5.00 \\
\hline containing $1.79 \mathrm{mM} \mathrm{NH}_{4} \mathrm{NO}_{3}$, & Rhamnose & $11.00 \pm 1.05$ & - & - & - \\
\hline $\mathrm{D}, 7.38 \mu \mathrm{M}$ 2-iP, $0.76 \mathrm{mM}$ pro- & Xylose & $17.00 \pm 1.41$ & - & - & - \\
\hline line (embryogenic medium) & Arabinose & - & - & - & - \\
\hline without any carbon source & Maltose & $30.00 \pm 1.33$ & $6.00 \pm 0.81$ & $3.00 \pm 0.81$ & 15.00 \\
\hline b Average value \pm Standard & Mannose & $28.00 \pm 1.33$ & $2.00 \pm 0.47$ & - & - \\
\hline & Soluble starch & - & - & - & - \\
\hline
\end{tabular}

Germination percentage $(\%)$ 

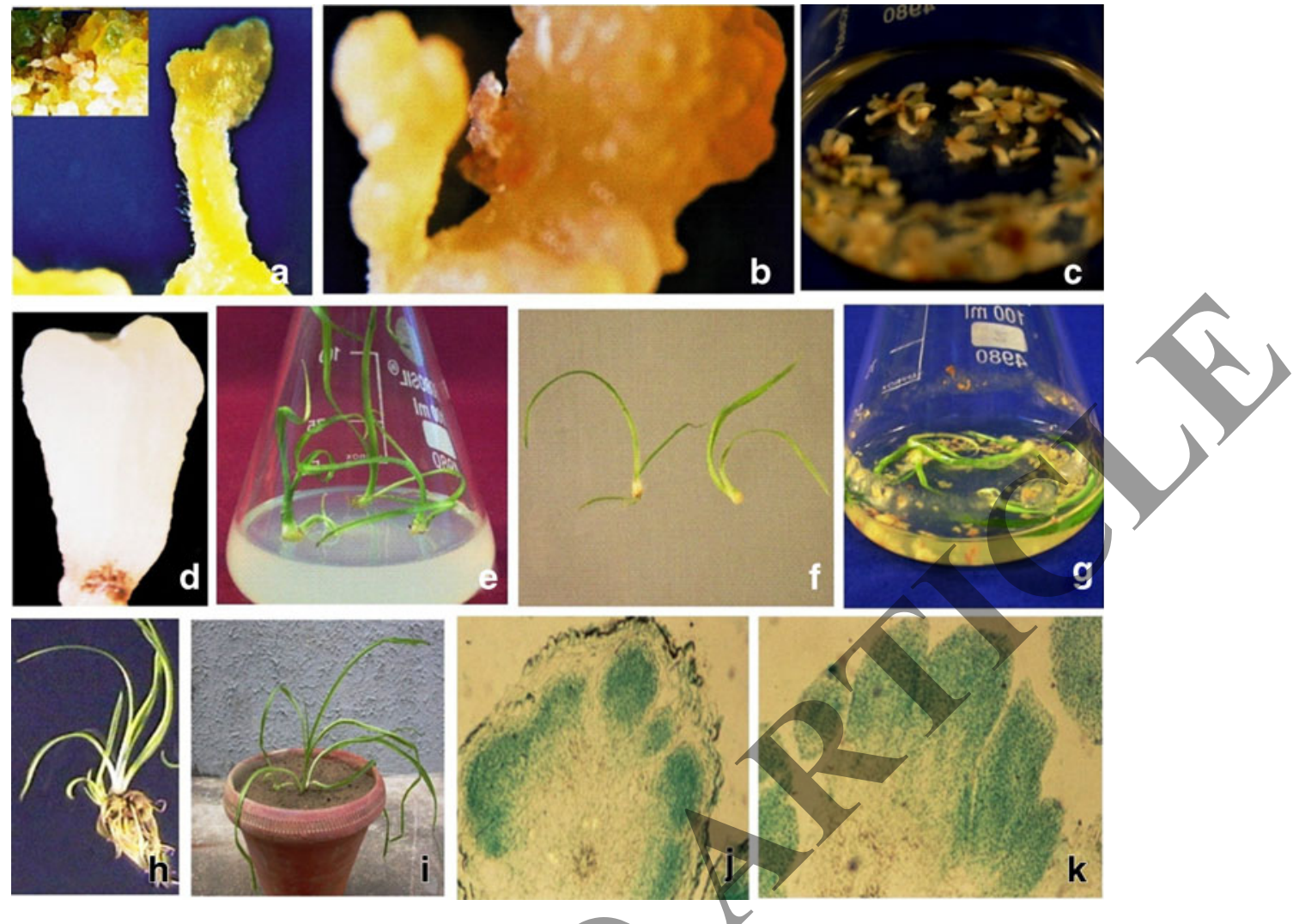

Fig. 1 Plant regeneration through somatic embryogenesis in C. borivilianum. a. mature somatic embryo on solid embryogenic medium [MS medium containing $1.79 \mathrm{mM} \mathrm{NH} \mathrm{NO}_{3}, 10.72 \mathrm{mM} \mathrm{KNO}$, $1.13 \mu \mathrm{M}$ 2,4-dichlorophenoxyacetic acid (2,4-D), $7.38 \mu \mathrm{M} 2$ isopentenyladenine (2-iP) and $0.76 \mathrm{mM}$ proline] with $3 \%$ sucrose after 4 weeks of culture (inset a. induction and development of somatic embryos on same medium); b. mature somatic embryo after 4 weeks of culture on solid embryogenic medium containing sucrose and PEG (polyethylene glycol), (3\% each); c. somatic embryos at different stages of maturation in liquid embryogenic medium after 4 weeks of culture; d. a mature somatic embryo in liquid medium; e. plantlets regenerated after 4 weeks of culture of mature somatic embryos on solid MS medium supplemented with $15.54 \mu \mathrm{M}$ 6-benzylaminopurine

while cellobiose was inhibitory to somatic embryogenesis. In the present investigation also sucrose (3\%) was best carbon source for somatic embryogenesis in C. borivilianum compared to other carbon sources which inhibited embryogenesis either partially or completely.

The embryogenic callus cultured on solid embryogenic medium containing $3 \%$ sucrose and D-mannitol or Dsorbitol (1-11\%) became necrotic and therefore somatic embryogenesis was inhibited at culture medium containing D-mannitol or D-sorbitol. While on the embryogenic medium supplemented with $3 \%$ each of PEG and sucrose, 1.88fold increase in number of mature somatic embryos was observed compared to control medium (embryogenic medium with $3 \%$ sucrose) (Table 2; Fig. 1b). Higher embryo germination $(50 \%)$ compared to only $30 \%$ on control medium was recorded, (Table 2) when mature somatic
(BAP), (somatic embryos matured on solid embryogenic medium containing $3 \%$ sucrose); f. plantlets regenerated after 4 weeks of culture of mature somatic embryos on solid MS medium having 15.54 $\mu \mathrm{M}$ BAP, [somatic embryos matured on embryogenic medium containing sucrose and PEG (3\% each)]; g. plantlets regenerated after 4 weeks of culture of somatic embryos on liquid MS medium containing $15.54 \mu \mathrm{M}$ BAP, (somatic embryos matured in liquid embryogenic medium); h. somatic embryo derived plantlet with developed root system after 6 weeks of culture; i. C. borivilianum plant regenerated through somatic embryogenesis in earthen pot after 11 weeks of hardening; j. globular somatic embryos appearing from surface of embryogenic cell mass in histological section; k. somatic embryos at advanced stage of maturation

embryos from medium containing PEG and sucrose (3\% each) were transferred to embryo germination medium (Fig. 1f). Amongst different ABA levels $(0.1-7.0 \mu \mathrm{M})$ tested, mature (cotyledonary stage) embryos were obtained only at $0.5 \mu \mathrm{M}$ and $1.0 \mu \mathrm{M}$ but the number of cotyledonary embryos were lower than even obtained on control medium (embryogenic medium with $3 \%$ sucrose only); (Table 3 ). Somatic embryo germination was observed only at $1.0 \mu \mathrm{M}$ ABA, recording only $5 \%$ germination frequency which was significantly lower than even on control medium (30\%). On other ABA levels $(0.1,3.0,5.0$ or $7.0 \mu \mathrm{M})$ embryo maturation and germination were completely inhibited (Table 3). Embryos became brown and necrotic and did not develop further.

Addition of sorbitol or mannitol to the embryogenic medium inhibited somatic embryogenesis in C. borivilianum in the present study consistent with the observations of 
Table 2 Effect of different osmotica and $3 \%$ sucrose on somatic embryo maturation and germination in C. borivilianum

${ }^{a}$ Embryogenic medium supplemented with $3 \%$ sucrose

${ }^{\mathrm{b}}$ Average value \pm Standard Error (SE)

- Callus cultured on solid embryogenic medium containing D-mannitol or D-sorbitol

$(1-11 \%)$ became necrotic and therefore somatic embryogenesis was inhibited

\begin{tabular}{|c|c|c|c|c|}
\hline $\begin{array}{l}\text { Osmoticum } \\
\text { concentration (\%) }\end{array}$ & $\begin{array}{l}\text { No. of total somatic } \\
\text { embryos }\end{array}$ & $\begin{array}{l}\text { No. of mature } \\
\text { (cotyledonary) embryos }\end{array}$ & $\begin{array}{l}\text { No. of embryos } \\
\text { germinated } / 20 \text { mature } \\
\text { embryos }\end{array}$ & $\begin{array}{l}\text { Germination } \\
\text { percentage }(\%)\end{array}$ \\
\hline
\end{tabular}

\begin{tabular}{lllll}
\hline Control $^{\mathrm{a}}$ & $44.00 \pm 2.21^{\mathrm{b}}$ & $17.00 \pm 1.24$ & $6.00 \pm 1.00$ & 30.00 \\
Polyethylene glycol (PEG) & & & \\
1 & $51.00 \pm 3.62$ & $28.00 \pm 2.0$ & $8.00 \pm 1.05$ & 40.00 \\
3 & $56.00 \pm 3.05$ & $32.00 \pm 3.67$ & $10.00 \pm 1.24$ & 50.00 \\
5 & $40.00 \pm 3.43$ & $18.00 \pm 2.16$ & $6.00 \pm 0.94$ & 30.00 \\
7 & $30.00 \pm 3.19$ & $12.00 \pm 1.19$ & $4.00 \pm 0.66$ & 20.00 \\
9 & $26.00 \pm 2.35$ & $8.00 \pm 1.05$ & $2.00 \pm 0.63$ & - \\
11 & $15.00 \pm 1.69$ & $4.00 \pm 0.81$ & - & - \\
Mannitol (1-11) & - & - & - & - \\
Sorbitol (1-11) & - & - & - & \\
\hline
\end{tabular}

Eapen and George (1990) and Walker and Parrott (2001) in peanut and soybean respectively. On the other hand in present investigation, PEG was effective in promoting embryo maturation and germination, reported in C. borivilianum for first time. In earlier studies, low somatic embryo germination rates $(20 \%$ and $30 \%$ ) were reported by Purohit et al. (1994) and Rizvi et al. (2010) respectively, compared to higher germination rate $(50 \%)$ recorded in the present study on PEG containing medium. In Phoenix dactylifera (Alkhateeb 2006) also addition of PEG to sucrose containing medium improved maturation and germination frequency of somatic embryos.

\section{Physical state of medium}

Compared to solid culture medium (embryogenic medium containing $3 \%$ each of sucrose and PEG and $0.8 \%$ agar), liquid medium (without agar) supported better growth and maturation of somatic embryos (Table 4). An average of total 66 somatic embryos were observed in líquid medium compared to only 54 on solid medium. The number of cotyledonary stage (mature) somatic embryos, their fresh weight and germination rate were also higher in liquid medium (Table 4; Fig. 1g). Somatic embryos induced and developed in liquid medium were transluscent, whitish and long (Fig. 1c, d). Therefore in the present study liquid medium was found to be more effective for somatic embryogenesis than agarsolidified medium in $C$. borivilianum. In earlier studies of Martin (2003) and Othmani et al. (2009) liquid suspension culture was reported to be superior for somatic embryogenesis as compared to agar-solidified medium. Regeneration through somatic embryogenesis in $C$. borivilianum using liquid medium has not been reported so far. For scale-up of cultures in bioreactors for mass propagation of plants, liquid culture medium has been recommended (Kim et al. 2004; Paek et al. 2005). The large-scale propagation of plants through somatic embryogenesis in liquid medium has a number of advantages compared to solid medium such as constant availability of embryogeniccompetent cells, opportunities for bioprocess automation and reduced manual labour. Liquid medium is more cost-effective than solid medium as agar which is a commonly used solidifying agent adds upto $65 \%$ of the cost of the culture medium (Mitra et al. 1998).
Table 3 Effect of different ABA levels on maturation and germination of somatic embryos in C. borivilianum

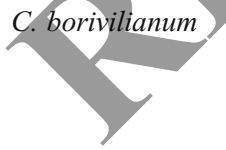

${ }^{a}$ Embryogenic medium supplemented with $3 \%$ sucrose

${ }^{\mathrm{b}}$ Average value \pm Standard Error (SE)

- No response

\begin{tabular}{lllll}
\hline $\begin{array}{l}\text { ABA concentration } \\
(\mu \mathrm{M})\end{array}$ & $\begin{array}{l}\text { No. of total somatic } \\
\text { embryos }\end{array}$ & $\begin{array}{l}\text { No. of mature } \\
\text { (cotyledonary) embryos }\end{array}$ & $\begin{array}{l}\text { No. of embryos } \\
\text { germinated/20 mature } \\
\text { embryos }\end{array}$ & $\begin{array}{l}\text { Germination } \\
\text { percentage }(\%)\end{array}$ \\
\hline Control $^{\mathrm{a}}$ & $44.00 \pm 2.21^{\mathrm{b}}$ & $17.00 \pm 1.24$ & $6.00 \pm 1.00$ & 30 \\
0.1 & $5.00 \pm 0.63$ & - & - & - \\
0.5 & $14.00 \pm 1.22$ & $2.00 \pm 0.47$ & - & 5 \\
1.0 & $20.00 \pm 1.41$ & $4.00 \pm 0.66$ & $1.00 \pm 0.47$ & - \\
3.0 & - & - & - & - \\
5.0 & - & - & - & - \\
7.0 & - & - & - & \\
\hline
\end{tabular}


Table 4 Effect of different physical states of medium on somatic embryogenesis

\begin{tabular}{|c|c|c|c|c|c|c|}
\hline $\begin{array}{l}\text { Physical state } \\
\text { of medium }\end{array}$ & $\begin{array}{l}\text { No. of total } \\
\text { somatic embryos }\end{array}$ & $\begin{array}{l}\text { No. of globular } \\
\text { somatic embryos }\end{array}$ & $\begin{array}{l}\text { No. of mature } \\
\text { (cotyledonary) embryos }\end{array}$ & $\begin{array}{l}\text { Fresh wt. (g) } \\
\text { of somatic embryos }\end{array}$ & $\begin{array}{l}\text { No. of embryos } \\
\text { germinated/20 } \\
\text { mature embryos }\end{array}$ & $\begin{array}{l}\text { Germination } \\
\text { percentage }(\%)\end{array}$ \\
\hline Solid (control) ${ }^{\mathrm{a}}$ & $54.00 \pm 3.16^{\mathrm{b}}$ & $16.00 \pm 1.58$ & $26.00 \pm 2.12$ & $0.19 \pm 0.02$ & $10.00 \pm 1.24$ & 50.00 \\
\hline Liquid & $66.00 \pm 3.87$ & $20.00 \pm 2.23$ & $32.00 \pm 2.34$ & $0.28 \pm 0.03$ & $10.60 \pm 1.34$ & 53.00 \\
\hline
\end{tabular}

${ }^{\text {a }}$ Agar-solidified ( $0.8 \%$ ) embryogenic medium supplemented with sucrose and PEG (3\% each)

${ }^{\mathrm{b}}$ Average value \pm Standard Error (SE)

\section{Casein acid hydrolysate}

Casein acid hydrolysate $(\mathrm{CH})$ did not have any stimulatory effect on somatic embryogenesis in C. borivilianum. Amongst different $\mathrm{CH}$ levels tested (1-4 \%), mature (cotyledonary stage) somatic embryos were observed only at $1 \%$ and $2 \% \mathrm{CH}$ levels. But their number was significantly lower compared to control medium (liquid embryogenic medium with $3 \%$ each of sucrose and PEG). At other $\mathrm{CH}$ levels tested (3\% and $4 \%$ ), embryos were in globular stage (Table 5). In liquid medium having different $\mathrm{CH}$ levels $(1-4 \%)$ root like structures developed from cell aggregates and cultures turned nonembryogenic. Germination of somatic embryos was completely inhibited at all tested levels (1-4\%) of $\mathrm{CH}$ (Table 5). In suspension cultures of Dactylis glomerata, casein hydrolysate stimaulated the root development (Gray and Conger 1985) consistent with the observations in the present study in C. borivilianum. In Picea glauca somatic embryos matured in the preseence of casein hydrolysate while amino acid glutamine was absent from the culture medium (Malabadi et al. 2011). In the studies of Cardoza and D'Souza (1999), supplementation of casein hydrolysate to half strength MS medium increased the somatic embryogenesis and plant/regeneration from somatic embryos. Casein hydrolysate enhanced somatic embryo induction and plant regeneration in sugarcane calli also (Nasir et al. 2011).

\section{Inoculum density}

Maturation of somatic embryos was promoted at lower inoculum density levels $(0.1-0.4 \mathrm{~g} / 40 \mathrm{ml}$ culture medium) while at higher inoculum density leyels $(0.6-1.0 \mathrm{~g} / 40 \mathrm{ml}$ culture medium), low maturation was observed. The highest average number of total somatic embryos (79), mature embryos (38) and highest fresh weight of somatic embryos were observed at $0.4 \mathrm{~g} / 40 \mathrm{ml}$ inoculum density level (Table 6). Mature sømatic embryos produced on 0.4 $\mathrm{g} / 40 \mathrm{ml}$ inoculum density level exhibited highest germination $(57.5 \%$ ) on transfer to embryo germination medium (Table 6). Embryo germination decreased at inoculum density levels more than $0.4 \mathrm{~g} / 40 \mathrm{ml}$ and was completely inhibited at $1.0 \mathrm{~g} / 40 \mathrm{ml}$ inoculum density level. Highest embryo germination was observed at $0.4 \mathrm{~g} / 40 \mathrm{ml}$ inoculum density level which exhibited highest somatic embryo maturation rate. In embryogenic suspension cultures, cell density could be an important factor that affects somatic embryogenesis. A relatively lower cell density favours the maturation of embryos from embryogenic cells (Fujimura and Komamine 1979) while a high cell density does not promotes the maturation of embryos (Nomura and Komamine 1985). This may be due to the secretion of proteins and/or other cellular factors into the culture medium (Gavish et al. 1992). In the present investigation inoculum density of $0.4 \mathrm{~g} / 40 \mathrm{ml}$ of medium was optimal for maturation of somatic embryos. Higher inoculum densities
Table 5 Effect of different levels of casein acid hydrolysate on somatic embryogenesis

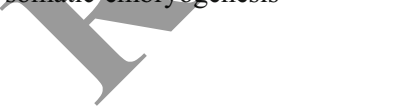

${ }^{a}$ Liquid embryogenic medium supplemented with sucrose and PEG (3\% each)

${ }^{\mathrm{b}}$ Average value \pm Standard Error (SE)

- No response

\begin{tabular}{lllllll}
\hline $\begin{array}{l}\text { Casein acid } \\
\text { hydrolysate } \\
(\%)\end{array}$ & $\begin{array}{l}\text { No. of total } \\
\text { somatic } \\
\text { embryos }\end{array}$ & $\begin{array}{l}\text { No. of } \\
\text { globular } \\
\text { somatic } \\
\text { embryos }\end{array}$ & $\begin{array}{l}\text { No. of mature } \\
\text { (cotytledonary) } \\
\text { somatic embryos }\end{array}$ & $\begin{array}{l}\text { Fresh wt. } \\
\text { (g) of } \\
\text { somatic } \\
\text { embryos }\end{array}$ & $\begin{array}{l}\text { No. of embryos } \\
\text { germinated/20 } \\
\text { mature embryos }\end{array}$ & $\begin{array}{l}\text { Germination } \\
\text { percentage } \\
(\%)\end{array}$ \\
\hline Control $^{\mathrm{a}}$ & $79.00 \pm 5.09^{\mathrm{b}}$ & $22.00 \pm 1.87$ & $38.00 \pm 2.34$ & $0.32 \pm 0.02$ & - & - \\
1 & $35.00 \pm 2.83$ & $21.00 \pm 2.12$ & $4.00 \pm 0.70$ & $0.14 \pm 0.02$ & - & - \\
2 & $44.00 \pm 3.93$ & $26.00 \pm 2.34$ & $7.00 \pm 0.80$ & $0.18 \pm 0.03$ & - & - \\
3 & $20.00 \pm 2.0$ & $15.00 \pm 1.58$ & - & $0.08 \pm 0.01$ & - & - \\
4 & $15.00 \pm 2.0$ & $12.00 \pm 1.22$ & - & $0.06 \pm 0.02$ & - & - \\
\hline
\end{tabular}


Table 6 Effect of different inoculum densities on maturation and germination of somatic embryos in C. borivilianum

\begin{tabular}{|c|c|c|c|c|c|c|}
\hline $\begin{array}{l}\text { Inoculum density } \\
\text { ( } \mathrm{g} \text { of cell aggregates } / 40 \mathrm{ml} \\
\text { of liquid medium) }\end{array}$ & $\begin{array}{l}\text { No. of total } \\
\text { somatic } \\
\text { embryos }\end{array}$ & $\begin{array}{l}\text { No. of } \\
\text { globular } \\
\text { somatic } \\
\text { embryos }\end{array}$ & $\begin{array}{l}\text { No. of mature } \\
\text { (cotytledonary) } \\
\text { somatic embryos }\end{array}$ & $\begin{array}{l}\text { Fresh wt. (g) } \\
\text { of somatic } \\
\text { embryos }\end{array}$ & $\begin{array}{l}\text { No. of embryos } \\
\text { germinated } / 20 \\
\text { mature embryos }\end{array}$ & $\begin{array}{l}\text { Germination } \\
\text { percentage }(\%)\end{array}$ \\
\hline 0.10 & $40.00 \pm 3.39^{\mathrm{b}}$ & $14.00 \pm 1.58$ & $16.00 \pm 1.22$ & $0.16 \pm 0.02$ & $6.00 \pm 0.94$ & 30.00 \\
\hline $0.15{\text { (control })^{\mathrm{a}}}$ & $66.00 \pm 3.87$ & $20.00 \pm 2.23$ & $32.00 \pm 2.34$ & $0.28 \pm 0.03$ & $10.60 \pm 1.34$ & 53.00 \\
\hline 0.20 & $61.00 \pm 3.80$ & $17.00 \pm 1.87$ & $28.00 \pm 2.00$ & $0.24 \pm 0.02$ & $10.00 \pm 1.24$ & \\
\hline 0.40 & $79.00 \pm 5.09$ & $22.00 \pm 1.87$ & $38.00 \pm 2.34$ & $0.32 \pm 0.02$ & $11.50 \pm 1.22$ & \\
\hline 0.60 & $55.00 \pm 3.80$ & $23.00 \pm 1.87$ & $18.00 \pm 1.58$ & $0.21 \pm 0.02$ & $7.00 \pm 0.89$ & \\
\hline 0.80 & $38.00 \pm 3.16$ & $19.00 \pm 1.58$ & $8.00 \pm 1.00$ & $0.15 \pm 0.01$ & $2.00 \pm 0.63$ & \\
\hline 1.00 & $30.00 \pm 2.24$ & $21.00 \pm 2.12$ & $4.00 \pm 1.00$ & $0.13 \pm 0.01$ & - & \\
\hline
\end{tabular}

${ }^{\mathrm{a}}$ Liquid embryogenic medium supplemented with sucrose and PEG (3\% each) and inoculum density of $0.15 \mathrm{~g} / 40 \mathrm{ml}$ of medium ${ }^{\mathrm{b}}$ Average value \pm Standard Error (SE)

- No response

( $>0.4 \mathrm{~g} / 40 \mathrm{ml}$ of medium) did not favoured development and maturation of embryos. In banana hybrid cultivar FHIA18 (AAAB), inoculum density of $0.6 \mathrm{~g} / 25 \mathrm{ml}$ of culture medium was best for somatic embryo growth and multiplication (Kosky et al. 2002). Inoculum density of $3.0 \mathrm{~g} / 20 \mathrm{ml}$ of medium (with $3 \%$ sucrose) showed a 2 -fold increase in cell growth in Lilium $\mathrm{x}$ formolongi Hort. cv. Norikula (Ho et al. 2006) while higher inoculum densities ( 3.5 and $4.0 \mathrm{~g} / 20 \mathrm{ml})$ were unfavourable for the growth.

\section{pH levels}

Maturation of somatic embryos was promoted between 4.86 and $6.86 \mathrm{pH}$ levels, while at acidic ( $\mathrm{pH}$ level 3.86) and alkaline (pH level 7.86) media, most of the embryos were in globular stage and their maturation was suppressed. Highest somatic embryo maturation and fresh weight were observed in embryogenic liquid culture medium at $\mathrm{pH}$ level 5.86 (control), (Table 7). Mature embryos produced at this
$\mathrm{pH}$ level exhibited highest (57.5\%) embryo germination when transferred to embryo germination medium (Table 7). It appears that $\mathrm{pH}$ requirements are species specific and developmental stage dependent. In banana hybrid cultivar FHIA-18 (AAAB), acidic medium (pH level 3.8) resulted in inhibition of embryo maturation $(87.2 \%$ globular stage embryos), (Kosky et al. 2002). Smith and Krikorian (1990) also reported that in carrot lower $\mathrm{pH}$ level (acidic medium) supported embryo development only upto pre-globular stage. The effect of high or low $\mathrm{pH}$ on inhibition of embryo development may be subsequently utilized for synchronization of somatic embryos to the initial stages of embryo development. The homogeneity thus obtained in embryo development will be beneficial in handling cultures for plant propagation through somatic embryogenesis at large-scale.

Plants regenerated in vitro through somatic embryogenesis and established in glass house were compared for their morphological characters viz. leaf length, leaf width, leaf colour, root length, weight etc. after 12 weeks of transplantation in

Table 7 Effect of different $\mathrm{pH}$ levels on somatic embryogenesis

\begin{tabular}{lllllll}
\hline $\mathrm{pH}$ levels & $\begin{array}{l}\text { No. of total } \\
\text { somatic } \\
\text { embryos }\end{array}$ & $\begin{array}{l}\text { No. of globular } \\
\text { somatic embryos }\end{array}$ & $\begin{array}{l}\text { No. of mature } \\
\text { (cotytledonary) } \\
\text { somatic embryos }\end{array}$ & $\begin{array}{l}\text { Fresh wt. (g) of } \\
\text { somatic embryos }\end{array}$ & $\begin{array}{l}\text { No. of embryos } \\
\text { germinated/20 mature } \\
\text { embryos }\end{array}$ \\
\hline 3.86 & $39.00 \pm 2.55^{\mathrm{b}}$ & $19.00 \pm 1.58$ & $7.00 \pm 1.22$ & $0.16 \pm 0.02$ & - & $\begin{array}{l}\text { Germination } \\
\text { percentage (\%) }\end{array}$ \\
4.86 & $68.00 \pm 4.47$ & $21.00 \pm 1.41$ & $29.00 \pm 2.12$ & $0.27 \pm 0.03$ & $7.00 \pm 0.71$ & 35.00 \\
$5.86\left(\right.$ control) ${ }^{\mathrm{a}}$ & $79.00 \pm 5.09$ & $22.00 \pm 1.87$ & $38.00 \pm 2.34$ & $0.32 \pm 0.02$ & $11.50 \pm 1.22$ & 57.50 \\
6.86 & $52.00 \pm 4.06$ & $15.00 \pm 1.00$ & $23.00 \pm 2.12$ & $0.21 \pm 0.02$ & $7.60 \pm 0.89$ & 38.00 \\
7.86 & $27.00 \pm 2.73$ & $13.00 \pm 1.22$ & $7.00 \pm 1.0$ & $0.11 \pm 0.01$ & - & - \\
\hline
\end{tabular}

${ }^{\mathrm{a}}$ Liquid embryogenic medium supplemented with sucrose and PEG (3 \% each) and inoculum density of $0.15 \mathrm{~g} / 40 \mathrm{ml}$ of medium with $5.86 \mathrm{pH}$ level

${ }^{\mathrm{b}}$ Average value \pm Standard Error (SE)

- No response 
pots. Performance of these plants was uniform and they were morphologically similar as compared to the mother plant (Fig. 1h, i). The average leaf length in regenerated plants was $13.7 \mathrm{~cm}$ while average leaf width was $1.10 \mathrm{~cm}$. The shoots of regenerated plants were green. About 4-5 fasciculed storage roots with an average length of $3.97 \mathrm{~cm}$ and mean fresh weight of $5.10 \mathrm{~g}$ could be produced per plant. These roots were also morphologically similar to the mother plant. Out of 70 plantlets, 56 survived after 12 weeks of transfer to pots thus exhibiting $80 \%$ survival of regenerated plants.

\section{Histology}

In histological examination, globular embryos were shown to appear from embryogenic cell masses which developed into mature cotyledonary embryos thus initiating bipolar structure (Fig. 1j, k).

Genetic fidelity of in vitro regenerated plants: RAPD analysis

In order to confirm genetic fidelity of somatic embryo derived plants, comparision of RAPD band pattern of plants regenerated in vitro through somatic embryogenesis and mother plant was carried out. Genetic fidelity of randomly selected 17 micropropagated plants out of a total progeny of 56 plants established in glass house along with mother plant was tested. Out of 20 different MAP primers tested, 15 primers accounting for $75 \%$ of the total primers used, exhibited amplification. Amongst these, MAP 02, MAP 08, MAP 09, MAP 10, MAP 12, MAP 14, MAP 16, MAP
17, MAP 18 and MAP 20 were selected on the basis of their amplification products which revealed clear fragmentation of DNA. The pattern of amplification was reproducible. Although total 51 RAPD bands were produced through amplification with these selected primers but only 47 bands which resolved clearly on the gel, were taken into consideration. Out of these 47 bands, 46 bands were monomorphic and 1 was polymorphic in nature. In the present study $98.33 \%$ monomorphism was exhibited by the randomly selected plants of $C$. borivilianum regenerated through somatic embryogenesis (Table 8). The representative RAPD profile of 17 sample plants raised through somatic embryogenesis and mother plant with three MAP primers (MAP 14, MAP 18 and MAP 20) has been shown in Fig. 2a-c. The number of scorable bands amplified with a given primer ranged from 2 (MAP 02 and MAP 12) to 8 (MAP 08). The size of the DNA fragments produced by selected 10 primers ranged from 125 to 5,148 bp (Table 8).

An important aspect of micropropagation protocols for commercial purposes is the genetic integrity of plants. Long term multiplication may lead to somaclonal or epigenetic variations in the micropropagated plants questioning the fidelity of their clonal nature (Cecchini et al. 1992; Rani and Raina 1998). Therefore, it is important to first establish the suitability of the micropropagation protocol developed with respect to the production of genetically identical and stable plants. The random amplified polymorphic DNA (RAPD), (Williams et al. 1990) is efficient, cost-effective and simple technique. This method often yields large number of markers; does not need either large amounts of DNA or previous information of DNA sequences. Moreover,

Table 8 Description of 10 decamer primers used for RAPD analysis of C. borivilianum plants regenerated through somatic embryogenesis and mother plant

\begin{tabular}{|c|c|c|c|c|c|c|c|c|}
\hline \multirow[t]{2}{*}{ S No } & \multirow[t]{2}{*}{ Primer } & & \multirow{2}{*}{$\begin{array}{l}\text { Total no. } \\
\text { of bands }\end{array}$} & \multicolumn{2}{|c|}{ Monomorphic bands } & \multicolumn{2}{|c|}{ Polymorphic bands } & \multirow{2}{*}{$\begin{array}{l}\text { Fragment size } \\
\text { of scored bands } \\
\text { (bp) }\end{array}$} \\
\hline & & & & No. of bands & Percentage $(\%)$ & No. of bands & Percentage $(\%)$ & \\
\hline 1 & MAP & 5'GTCCTACTCG3' & 2 & 2 & 100.00 & - & - & $831-1375$ \\
\hline 2 & MAP 0 & 5'CTATCGCCGC3' & 8 & 8 & 100.00 & - & - & $564-3530$ \\
\hline 3 & & 5'CGGGATCCGC3' & 5 & 5 & 100.00 & - & - & $947-2027$ \\
\hline & & 5'GCGAATTCCG3' & 5 & 5 & 100.00 & - & - & 564-1904 \\
\hline & MAP 1 & 5'CCCTGCAGGC3' & 2 & 2 & 100.00 & - & - & $831-1375$ \\
\hline 6 & MAP 14 & 5'GTGCAATGAG3' & 3 & 3 & 100.00 & - & - & $1904-3530$ \\
\hline 7 & MAP 16 & 5'AAGATAGCGG3' & 4 & 4 & 100.00 & - & - & $125-1375$ \\
\hline 8 & MAP 17 & 5'GGATCTGAAC3' & 6 & 6 & 100.00 & - & - & $1584-5148$ \\
\hline 9 & MAP 18 & 5'TTGTCTCAGG3' & 6 & 5 & 83.33 & 1 & 16.67 & 564-2027 \\
\hline \multirow[t]{2}{*}{10} & MAP 20 & 5'GGACTCCACG3' & 6 & 6 & 100.00 & - & - & $125-1584$ \\
\hline & Total & & 47 & 46 & 98.33 & 1 & 1.67 & \\
\hline
\end{tabular}

- No polymorphic bands were observed 

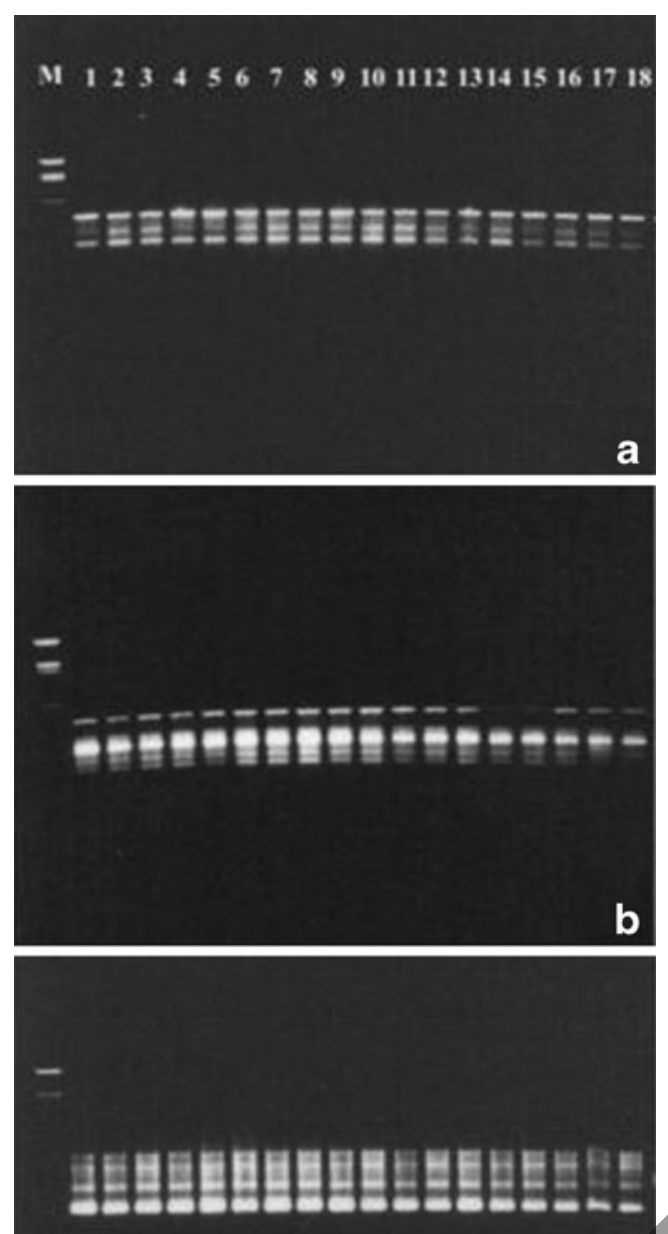

c

Fig. 2 RAPD profiles of $C$. borivilianum plants regenerated through somatic embryogenesis and mother plant on $1.2 \%$ agarose gel employing MAP primers. a. MAP 14; b MAP 18 and c MAP 20. Samples in gel lanes (from left to right) lane $1 \mathrm{M}$, molecular size marker (HindIII and EcoRI restricted $\lambda$ DNA marker); lane 2 mother plant; lane 3-19 plants raised through somatic embryogenesis after 12 weeks of their transfer in pots

RAPD analysis does not involve radioactive compounds. RAPD has been extensively used for studying genetic fidelity of in vitro raised plants in a number of species (Tyagi et al. 2007; Kumar et al. 2010; Nadha et al. 2011). In the present study, the bands amplified through RAPD by responsive primers showed monomorphism with the mother plant and were also similar among the in vitro raised plants thus indicating the genetic fidelity of the micropropagated plants. The genetic stability of plants regenerated in vitro via somatic embryos has been reported previously (Bennici et al. 2004; Yang et al. 2008; Patel et al. 2011). According to Bennici et al. (2004) the lack of variation in their Foeniculum vulgare in vitro regenerants may be due to developmental constraints which exert selection against variant cells during regeneration. Some investigators have also reported polymorphism in micropropagated plants using RAPD (Bindiya and Kanwar 2003; Elmeer et al. 2009; Peyvandi et al. 2010). Rani et al. (1995) found variations among micropropagated Populus deltoides plants originating from the same clone though they were morphologically similar.

In the present study efficient maturation and germination of $C$. borivilianum somatic embryos were established which resulted into production of high quality somatic embryos and subsequently healthy plants with high survival rate. An efficient protocol for high frequeney plant multiplication employing embryogenic suspension culture has been scaled-up at shake flask level which may be used for large-scale multiplication of $C$. borivilianum in bioreactor. The observation of $98.33 \%$ monomorphism between plants regenerated through somatic embryogenesis and mother plant lead us to conclude that plants regenerated by somatic embryogenesis in the present study are genetically true to the plant of origin. Therefore suitability of the protocol developed for micropropagation of $C$. borivilianum via somatic embryogenesis with respect to the production of genetically identical and stable plants has been demonstrated which enhances the utility of the protocol developed in the present study.

Acknowledgements The necessary facilities provided by Director, Central Institute of Medicinal and Aromatic Plants and financial support of Council of Scientific and Industrial Research, India as Senior Research Fellowship to M. Z. Rizvi are duly acknowledged.

\section{References}

Alkhateeb AA (2006) Somatic embryogenesis in date palm (Phoenix dactylifera $\mathrm{L}$ ) cv sukary in response to sucrose and polyethylene glycol. Biotech 5(4):466-470

Bennici A, Anzidei M, Vendramin GG (2004) Genetic stability and uniformity of Foeniculum vulgare Mill. regenerated plants through organogenesis and somatic embryogenesis. Plant Sci 166:221-227

Bindiya K, Kanwar K (2003) Random amplified polymorphic DNA (RAPDs) markers for genetic analysis in micropropagated plants of Robinia pseudoacacia L. Euphytica 132:41-47

Bordia PC, Joshi A, Simlot MM (1995) Safed musli. In: Chadha KL, Gupta R (eds) Advances in horticulture: medicinal and aromatic plants, vol 11. Malhotra Pub House, New Delhi, pp 429-451

Cardoza V, D'Souza L (1999) Somatic embryogenesis and plantlet regeneration in Mussaenda philippica var Aurorae. Gartenbauwissenschaft 64(1):S6-S8

Cecchini E, Natah L, Cavallini A, Durante M (1992) DNA variation in regenerated plants of pea. Theor Appl Genet 84:874-879

Eapen S, George L (1990) Influence of phytohormones, carbohydrates, amino acids, growth supplements and antibiotics on somatic embryogenesis and plant differentiation in finger millet. Plant Cell Tissue Organ Cult 22:87-93 
Elmeer KMS, Gallagher TF, Hennerty MJ (2009) RAPD-based detection of genomic instability in cucumber plants derived from somatic embryogenesis. African J Biotechnol 8(14):3219-3222

Fujimura T, Komamine A (1979) Synchronization of somatic embryogenesis in a carrot suspension culture. Plant Physiol 64:162-164

Gavish H, Vardi A, Fluhr R (1992) Suppression of somatic embryogenesis in Citrus cell cultures by extracellular proteins. Planta 186:511-517

Gerdakaneh M, Mozafari AA, Khalighi A, Sioseh-mardah A (2009) The effect of carbohydrate source and concentration on somatic embryogenesis of strawberry (Fragaria x ananassa Duch). Am Eurasian J Agric Environ Sci 6(1):76-80

Gray DJ, Conger BV (1985) Influence of dicamba and casein hydrolysate on somatic embryo number and culture quality in cell suspensions of Dactylis glomerata (Gramineae). Plant Cell Tissue Organ Cult 4(2):123-133

Gupta R, Chadha KL (1995) Medicinal and aromatic plants research in India. In: Chadha RK, Gupta R (eds) Advances in horticulture, vol XI. Malhotra Pub House, New Delhi, pp 1-43

Ho CW, Jian WT, Lai HC (2006) Plant regeneration via somatic embryogenesis from suspension cell cultures of Lilium $\mathrm{x}$ formolongi Hort using a bioreactor system. in vitro Cell Dev Biol Plant 42:240-246

Hong PI, Chen JT, Chang WC (2008) Promotion of direct somatic embryogenesis of Oncidium by adjusting carbon sources. Biol Plant 52(3):597-600

Jayanthi M, Mandal PK (2001) Plant regeneration through somatic embryogenesis and RAPD analysis of regenerated plants in Tylophora indica (Burm F Merrill). in vitro Cell Dev Biol Plant 37:576-580

Khanuja SPS, Shasanay AK, Darokar MP, Kumar S (1999) Rapid isolation of DNA from dry and fresh samples of plants producing large amounts of secondary metabolites and essential oils. Plant Mol Biol Rep 17:74

Khanuja SPS, Shasany AK, Srivastava A, Kumar S (2000) Assessment of genetic relationships in Mentha species. Euphytica 111:121-125

Kim EK, Hahn EJ, Murthy HN, Paek KY (2004) Enhanced shoot and bulblet proliferation of garlic (Allium sativam $\mathrm{L}$ ) in bioreactor systems. J Hortic Sci 79:818-822

Kirtikar KR, Basu BD (1975) Liliaceae: Chlorophytum. In: Kirtikar KR, Basu BD (eds) Indian medicinal plants. Bishan Singh Mahendra Pal Singh, Dehradun, pp 2508-2509

Kosky RG, de Feria Silva MD, Perez LP, Gilliard T, Martinez FB, Vega MR, Milian MC, Mendoza EQ (2002) Somatic embryogenesis of the banana hybrid cultivar FHIA-(AAAB) in liquid medium and scaled-up in a bioreactor. Plant Cell Tissue Organ Cult 68:21-26

Kumar N, Modi AR, Singh AS, Gajera BB, Patel AR, Patel MP, Subhash N (2010) Assessment of genetic fidelity of micropropagated date palm (Phoenix dactylifera L) plants by RAPD and ISSR markers assay. Physiol Mol Biol Plants 16(2):207-213

Malabadi RB, da Silva JAT, Nataraja K, Kumar SV, Mulgund GS (2011) Induetion of somatic embryogenesis in mature coniferous forest trees. Res Biotech 2(5):8-33

Martin KP (2003) Plant regeneration through somatic embryogenesis on Holostemma adakodien, a rare medicinal plant. Plant Cell Tissue Organ Cult 72:79-82

Mitra A, Bhattacharaya PS, Dey S, Sawarker SK, Bhattacharayya BC (1998) Photoautotrophic in vitro culture of Chrysanthemum under $\mathrm{CO}_{2}$ enrichment. Biotechnol Tech 12:335-337

Murashige T, Skoog FA (1962) A revised medium for rapid growth and bioassays with tobacco tissue cultures. Physiol Plant 15:473-497

Nadha HK, Kumar R, Sharma RK, Anand M, Sood A (2011) Evaluation of clonal fidelity of in vitro raised plants of Guadua angustifolia Kunth using DNA-based markers. J Med Plants Res 5 (23):5636-5641
Nasir IA, Jahangir GZ, Qamar Z, Rahman Z, Hasnain T (2011) Maintaining the regeneration potential of sugarcane callus for longer span. Afr J Agric Res 6(1):113-119

Nayar MP, Sastry ARK (1988) Chlorophytum borivilianum. In: Nayar MP, Sastry ARK (eds) Red data book of Indian plants, vol 2. Botanical survey of India, Calcutta, p 142

Nhut DT, Vinh BVT, Hien TT, Huy NP, Nam NB, Chien HX (2011) Effects of spermidine, proline and carbohydrate sources on somatic embryogenesis from main root transverse thin cell layers of Vietnamese ginseng (Panax vietnamensis Ha et Grushv). Afr J Biotechnol 11(5):1084-1091

Nomura K, Komamine A (1985) Identification and isolation of single cells that produce somatic embryos at a high frequency in a carrot suspension culture. Plant Physiol 79:988-991

Othmani A, Bayoudh C, Drira N, Trifi M (2009) in vitro cloning of date palm Phoenix dactylifera L, cv Deglet Bey by using embryogenic suspension and temporary immersion bioreactor (TIB). Biotechnol Biotechnol Equip 23:1181-1188

Paek KY, Chakrabarty D, Hahn EJ (2005) Application of bioreactor systems for large scale production of horticultural and medicinal plants. Plant Cell Tissue Organ Cult 81:287-300

Patel S, Jasrai YT, Adiyecha R (2011) Induction of somatic embryogenesis and genetic fidelity of endangered medicinal herb Curculigo orchioides Gaertn. Res Plant Biol 1(3):48-52

Peyvandi M, Farahzadi HN, Arbabian S, Noormohammadi Z, Hosseini-Mazinani M (2010) Somaclonal variation among somatic embryo derived plants of Olea europaea L “cv Kroneiki”. J IR Iran 21(1):7-14

Purohit SD, Dave A, Kukda G (1994) Somatic embryogenesis and plantlet regeneration in 'safed musli' (Chlorophytum borivilianum). Indián J Plant Genet Resour 7(1):65-71

Ramawat KG, Jain S, Suri SS, Arora DK (1988) Aphrodisiac plants of Aravalli Hills with special reference to safed musli. In: Khan I, Khanum A (eds) Role of biotechnology in medicinal and aromatic plants. Ukaz Pub, Hyderabad, pp 210-223

Rani V, Raina SN (1998) Genetic analysis of enhanced axillary branching derived Eucalyptus tereticornis Smith and E. camaldulensis Dehn plants. Plant Cell Rep 17:236-242

Rani V, Parida A, Raina SN (1995) Random amplified polymorphic DNA (RAPD) markers for genetic analysis in micropropagated plants of Populus deltoides Marsh. Plant Cell Rep 14:459-462

Rizvi MZ, Kukreja AK, Bisht NS (2010) in vitro propagation of an endangered medicinal herb Chlorophytum borivilianum Sant et Fernand through somatic embryogenesis. Physiol Mol Biol Plants 16(3):249-257

Smith DL, Krikorian AD (1990) Somatic embryogenesis of carrot in hormone-free medium: external $\mathrm{pH}$ control over morphogenesis. Am J Bot 77:1634-1647

Tandon M, Shukla YN (1995) Phytoconstituents of Asparagus adscendens, Chlorophytum arundinaceum and Curculigo orchioides: a review. Curr Res Med Aromat Plants 17:42-50

Tyagi RK, Agarwal A, Mahalakshmi C, Hussain Z, Tyagi H (2007) Low-cost media for in vitro conservation of turmeric (Curcuma longa $\mathrm{L}$ ) and genetic stability assessment using RAPD markers. in vitro Cell Dev Biol Plant 43:51-58

Walker DR, Parrott WA (2001) Effect of polyethylene glycol and sugar alcohols on soybean somatic embryo germination and conversion. Plant Cell Tissue Organ Cult 64:55-62

Williams JGK, Kubelick AR, Livak KJ, Rafalski JA, Tingey SV (1990) DNA polymorphisms amplified by arbitrary primers are useful as genetic markers. Nucleic Acids Res 18:6531

Yang XM, An LZ, Xiong YC, Zhang JP, Li Y, Xu SJ (2008) Somatic embryogenesis from immature zygotic embryos and monitoring the genetic fidelity of regenerated plants in grapevine. Biol Plant $52: 209-214$ 